\title{
Yield and competition in barley variety mixtures
}

\author{
KARI JOKINEN \\ Department of Crop Husbandry, University of Helsinki, \\ SF 00710 Helsinki, Finland
}

Present address:

Kemira Oy, Espoo Research Centre, P.O. Box 44, SF 02271 Espoo, Finland

\begin{abstract}
Competition between spring barley varieties and yield performance of two-, threeand four-variety mixtures were studied in two replacement series field experiments. In the first experiment, repeated in three successive years (1983-85) the components were the six-row varieties Agneta, Arra, Hja-673 and Pomo. In the second experiment (1984), including two nitrogen doses ( 50 and $100 \mathrm{kgN} / \mathrm{ha}$ ), both six-row (Agneta, Pomo) and two-row (Ida, Kustaa) varieties were used.

Arra in the first and Agneta in the second experiment were the most competitive varieties. The results suggested that the fast growth of Arra at the beginning promoted its competitive ability. Increase in available nitrogen usually strengthened the competitiveness of Agneta. The observed competitive differences between varieties were not related to the earliness of a variety, neither to the morphological characters (two- and six-row varieties) nor to the grain yield of a variety grown alone. The competitive ability was not always a stable character, the dominantsuppression relationship varying from one environment to another (e.g. growing season, nitrogen dose).

The observed overyielding was not statistically significant. The ratio of actual to expected yield and the relative yield total of several mixtures exceeded slightly one. As a conclusion, the yield advantage of mixtures was marginal. As a rule, the mixtures were not more stable than monocultures as determined by the coefficient of variation. However, the yield of some mixtures varied less than the yield of the most stable monoculture.
\end{abstract}

Index words: Competition, yield, barley, mixture

\section{INTRODUCTION}

Mixtures of field crops are still extensively grown in traditional agriculture, but where more mechanized methods are used, monocul- tures are more common. The plant communities with some degree of genotypic heterogeneity may have advantages over pure stands. These alleged advantages have included one or more of the following: higher yields, 
lower variability of yield from season to season, an even distribution of production over the growth period, less susceptibility to disease or lodging, and an improved quality of the crop product (TRENBATH 1974).

Also growing of variety mixtures, multilines or bulk hybrids instead of pure line varieties has been proposed as a means of obtaining higher and more stable yields. The mixture represents an obvious agronomic advantage in cases where the yield of the mixture exceeds the yield of the highest-yielding component grown in pure stand but in most cases the yields of the mixtures have been reported to be about the same as or slightly higher than that of the weighted mean of their components (Simmonds 1962, Allard and Adams 1969, Clay and Allard 1969, Sandfaer 1970, Blijenburg and SNeEP 1975, LANG et al. 1975, Eisenberg 1980, Nitzshe and Hesselbach 1983, Aufhammer et al. 1984, BaKer and Briggs 1984, Harrabi et al. 1986, HouMOller et al. 1986, KarJalainen and Hirvola 1987, Mcdonald et al. 1988, Aufhammer and Stutzel 1989).

In many experiments on varietal mixtures the yield advantage is not thoroughly assessed. This is because an analysis performed according to the de Wit model (relative yield total) (de Wit 1960, de WIT and van den BerG 1965 ) is in most cases impossible because only the total yield of a mixture is measured. In mixtures with relative yield total values (RYT) or land equivalent ratio values (LER) equal to unity where the highest-yielding component is the strongest competitor, the yield of the mixture will exceed the weighted mean of the components. However, this does not involve an agronomic advantage (WILley 1979, 1985). Only when RYT is greater than one is an agronomic advantage obvious.

The replacement series experiments described here were made to test the hypothesis that mixtures of different spring barley varieties contrasted in terms of maturity, and morphological properties would yield more than the same varieties grown separately, possibly through more efficient use of resources.
Different ways (see above) to evaluate the yield advantage of mixtures are to be considered. Besides the agronomically important yields also competitional interactions among barley varieties are elucidated.

\section{MATERIALS AND METHODS}

Two experiments were carried out between 1983 and 1985. Experiment 1 was repeated in three successive years. Experiment 2 was carried out once in 1984. The trials were located on the Viikki trial field, Helsinki University $\left(60^{\circ} 13^{\prime}, 25^{\circ} 00^{\prime} \mathrm{E}\right)$. The soil $\mathrm{pH}$ varied from 5.4 to 5.8 (soil types are presented in the section on crop husbandry). The size of the plot was $10 \mathrm{~m}^{2}(1.25 \mathrm{~m} \mathrm{x} 8 \mathrm{~m})$.

Experimental design. Experiment 1 was laid out in a randomized block design with four blocks, the plots containing 15 variety/mixture treatments. Experiment 2 was in a splitplot design with four blocks, each of the two main plots containing the nitrogen fertilizer treatments were split for the 15 variety/mixture treatments. In both experiments the varieties were mixed mechanically before sowing in all possible combinations (two-, three- and four-variety mixtures) in equal proportions (number of plants per area). Thus, eleven mixtures and four individual varieties were compared.

Varieties. In experiment 1, four highyielding six-row varieties (Arra, $\mathrm{Hja} \mathrm{673,}$ Agneta, Pomo) of contrasting maturity were chosen. The choice of varieties was made in order to harvest all the plots of the experiment at the same time. In experiment 2 , the varieties were Ida and Kustaa (two-row), and Agneta and Pomo (six-row) having different morphological characters (for example height, tillering capacity and grain size). The characters of the varieties shown in Table 1 are from long-term field trials (1979-86) carried out by the Agricultural Research Centre in southern Finland (RANTANEN and SimoJoKi 1987).

Crop husbandry. The plots were fertilized at the rate of $500 \mathrm{~kg} / \mathrm{ha}$ with compound fer- 
tilizer NPK (N 2\%, P 8\%, K $12 \%$ ). The amount of nitrogen was adjusted to $80 \mathrm{~kg}$ $\mathrm{N} /$ ha in experiment 1 and in experiment 2 to 50 and $100 \mathrm{~kg} \mathrm{~N} / \mathrm{ha}$ by calcium ammonium nitrate (CAN) (N 27\%). The fertilizers were applied between seed-bed preparation and sowing with a fertilizer drill to a depth of $8-12 \mathrm{~cm}$. Seeds were sown at a density of 500 viable seeds $/ \mathrm{m}^{2}$ by machine in rows with 12.5 $\mathrm{cm}$ spacing between rows. The crops were kept free of weeds by one application of the herbicide Actril S (2-3 liters/ha mixed with 300 liters of water) containing MCPA (235 g/l), dichlorprop (184 g/l), ioxynil (38 g/l) and bromoxynil $(24 \mathrm{~g} / \mathrm{l})$ at the time of shoot emergence. The trials (total area of each plot) were harvested by a combine harvester at the time when the latest variety reached its maturity stage (the analysed moisture content was under $30 \%$ ). The sowing dates, harvesting dates, number of days from sowing to harvesting and soil types were the following:

\begin{tabular}{cccccc} 
Exp. Year & $\begin{array}{l}\text { Sowing } \\
\text { date }\end{array}$ & \multicolumn{2}{l}{$\begin{array}{l}\text { Harvesting } \\
\text { date }\end{array}$} & $\begin{array}{l}\text { Number } \\
\text { of days }\end{array}$ & \\
\hline 1 & 1983 & 5 May & 4 August & 92 & Muddy clay \\
& 1984 & 4 May & 9 August & 98 & Muddy clay \\
& 1985 & 27 May & 26 August & 91 & Sandy clay \\
2 & 1984 & 22 May & 24 August & 94 & Sandy clay
\end{tabular}

Sampling and analyses. The number of seedlings was determined before the start of tillering and the number of generative shoots after the complete ear emergence in randomly chosen rows along $3 \times 1 \mathrm{~m}$ in each plot (or subplot). The density of all the stands corresponded to the amount of viable seeds sown $(0.95$ to 1.05 times as expected).

Four weeks after sowing in 1983 (exp. 1) samples were taken from three random 1-mlong rows/plot for determination of varietal characters (early growth and development) grown in monocultures. The same amount of plants was removed from mixture stands to avoid grain yield errors. The characters recorded were dry weight per plant, dry weight per main stem, leaf area of the four fully expanded growth leaves of the main shoot and height of the main shoot. The height of the main shoot (pseudostem) was measured from the point where adventitious roots start their growth to the point of the stipule of the latest leaf. Also the developmental stage of the varieties was evaluated by determining the number of tillers and number of fully expanded leaves.

The grain yields were determined $(\mathrm{kg} / \mathrm{ha}$ at $15 \%$ moisture content). From each mixture yield samples of 400 seeds were taken for determination of the seed yield of the components. The separated samples of each mixture as well as samples of each pure stand yield were used for determination of 1000 grain weights (g) in 1983 . The grain weight in mixtures was determined by dividing the weight of the fraction by the number of seeds. The grain weight of each monoculture was determined from samples of $3 \times 100$ seeds.

Dry weight per plant, leaf area, grain yields and 1000 grain weight were subjected to analyses of variance (randomized block design and split-plot design). Mean separation was accomplished by Tukey's honestly significant difference test (HSD) $(\mathrm{P}=0.05)$. The analyses were performed according to STEEL and TORRIE (1980).

Relative yields (RY) based on grain yields (weight/area) were calculated according to the formula (de WIT and van den BERG 1965) : $\mathrm{RY}=\mathrm{O} / \mathrm{M}$, where $\mathrm{O}$ is the yield of the variety (species) in mixture and $\mathrm{M}$ the yield of the variety (species) in pure stand.

Relative yield total (RYT) was calculated according to the formula (de WIT and van den BERG 1965):

$\mathrm{RYT}=\mathrm{RY} 1+\mathrm{RY} 2 \ldots+\mathrm{RYx}$, where RY1, RY2 and ...RYx are the relative yields of variety (species) $1,2 \ldots x$ respectively.

Competitive ratio (CR) is used as a measure of intercrop (-varietal) competition. The competitive ratio is calculated according to the formula (WILLEY and RAO 1980)

$\mathrm{CR} 1=(\mathrm{RY} 1 / \mathrm{RY} 2) \times(\mathrm{Z} 2 / \mathrm{Z} 1)$, where $\mathrm{Z} 1$ is the proportion of intercropped 
Table 1. General characters of the varieties (RANTANEN and SIMOJOKI 1987).

\begin{tabular}{|c|c|c|c|c|c|}
\hline Variety & $\begin{array}{l}\text { Grain yield } \\
\mathrm{kg} / \mathrm{ha}\end{array}$ & $\begin{array}{l}\text { Growing } \\
\text { time } \\
\text { days }\end{array}$ & $\begin{array}{l}\text { Height } \\
\mathrm{cm}\end{array}$ & $\begin{array}{c}1000- \\
\text { grain weight } \\
\mathrm{g}\end{array}$ & $\begin{array}{c}\text { Grain } \\
\text { protein } \\
\text { content } \% \\
\end{array}$ \\
\hline $\begin{array}{l}\text { Agneta (6-row) } \\
\text { (Svalöv 1978) }\end{array}$ & $\begin{array}{c}5100 \\
(=100)\end{array}$ & 87 & 81 & 37.2 & 12.0 \\
\hline $\begin{array}{l}\text { Arra (6-row) } \\
\text { (Jokioinen 1982) }\end{array}$ & 92 & 83 & 84 & 38.1 & 12.9 \\
\hline $\begin{array}{l}\text { Hja } 673 \text { (6-row) } \\
\text { (Hankkija 1973) }\end{array}$ & 92 & 83 & 85 & 34.0 & 11.7 \\
\hline $\begin{array}{l}\text { Pomo (6-row) } \\
\text { (Jokioinen 1969) }\end{array}$ & 90 & 90 & 83 & 37.5 & 11.9 \\
\hline $\begin{array}{l}\text { Ida (2-row) } \\
\text { (Weibulsholm 1979) }\end{array}$ & 97 & 91 & 70 & 44.9 & 12.8 \\
\hline $\begin{array}{l}\text { Kustaa (2-row) } \\
\text { (Svalöv 1980) }\end{array}$ & 92 & 93 & 67 & 42.9 & 11.9 \\
\hline
\end{tabular}

area initially allocated to variety (species) 1 and $\mathrm{Z2}$ is the proportion of intercropped area initially allocated to variety (species) 2 . Thus the CR term is therefore simply the ratio of the individual RYs of the two component crops, but corrected for the proportions in which the crops were intially sown.

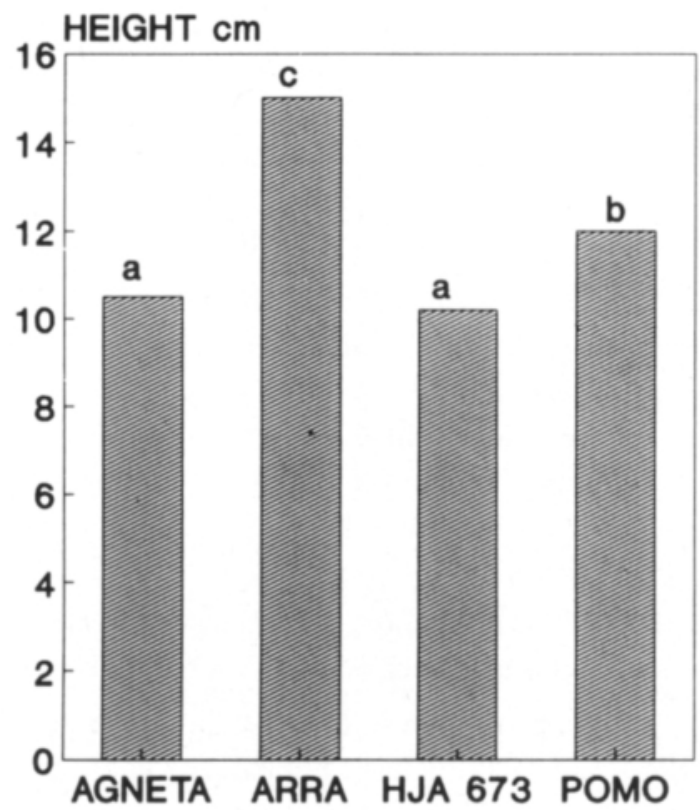

Figure 1. Height of the main stem of different barley cultivars grown in monoculture for four weeks in 1983. Means followed by the same letter are not significantly different at the $5 \%$ level (HSD test).
Actual yield (A) is the harvested yield of the mixture. Expected yield (E) of the mixture is the average of the yield of the monocultures included in a given mixture.

\section{RESULTS}

\section{The effect of the variety and growing seasons (Exp. 1)}

\section{Vegetative and generative development}

Evaluation of the early growth characters of the plants revealed significant differences between the varieties. Arra emerged first, followed by Pomo, Agneta and finally $\mathrm{Hja} 673$. The early variety Arra contained the greatest

Table 2. Phytomass accumulation (dry weight in $\mathrm{mg}$ ) of different barley cultivars grown in monocultures during the first month of growth in 1983. Dry weight means in the columns followed by the same letter are not significantly different at the 5\% level (HSD test).

\begin{tabular}{lcc}
\hline Cultivar & Phytomass/plant & Phytomass/main shoot \\
\hline Agneta & $193 \mathrm{a}$ & $166 \mathrm{ab}$ \\
Arra & $277 \mathrm{~b}$ & $241 \mathrm{c}$ \\
Hja 673 & $186 \mathrm{a}$ & $145 \mathrm{a}$ \\
Pomo & $235 \mathrm{ab}$ & $183 \mathrm{~b}$ \\
\hline
\end{tabular}


Table 3. Leaf area (LA in $\mathrm{mm}^{2}$ ) of different barley cultivars grown in monocultures after the first month of growth in $1983(\mathrm{~N}=120)$. Leaf area means in the columns followed by the same letter are not significantly different at the $5 \%$ level (HSD test).

\begin{tabular}{lccccc}
\hline Cultivar & \multicolumn{3}{c}{ Position of the leaf on the main shoot } & Total LA/main shoot \\
\cline { 2 - 4 } & 1 & 2 & 3 & 4 & $1305 \mathrm{~b}$ \\
\hline Agneta & $339 \mathrm{c}$ & $427 \mathrm{~b}$ & $776 \mathrm{~b}$ & $1269 \mathrm{~b}$ & $2847 \mathrm{~b}$ \\
Arra & $391 \mathrm{~d}$ & $521 \mathrm{c}$ & $752 \mathrm{~b}$ & $946 \mathrm{a}$ & $2935 \mathrm{~b}$ \\
Hja 673 & $219 \mathrm{a}$ & $309 \mathrm{a}$ & $503 \mathrm{a}$ & $1977 \mathrm{a}$ \\
Pomo & $279 \mathrm{~b}$ & $433 \mathrm{~b}$ & $819 \mathrm{~b}$ & $145 \mathrm{c}$ & $2986 \mathrm{~b}$ \\
\hline
\end{tabular}

phytomass (dry weight/plant and dry weight/main shoot) and the other early variety $\mathrm{Hja} 673$ the lowest (Table 2). The main shoot of Arra was the tallest (Fig. 1). The total leaf area and the leaf area of each leaf of Hja 673 was the smallest (Table 3).

The morphological advancement of the varieties varied (Table 4). Over $90 \%$ of the main shoots of the earliest varieties, Arra and $\mathrm{Hja}$ 673 , had the third complete leaf opened. The variety Arra had the lowest number of first order tillers, but the tillers were at the most advanced stage with $89 \%$ of the tillers having a fully opened leaf.

In pure stands the change of the growth stage from stem extension to heading started first in the Arra stand, followed by $\mathrm{Hja} \mathrm{673,}$ Agneta and finally Pomo. At the end of head-

Table 4. The morphological development of different barley cultivars grown in monocultures after the first month of growth in $1983(\mathrm{~N}=120)$.

\begin{tabular}{lccccrr}
\hline Cultivar & \multicolumn{6}{c}{ Stage of morphological development } \\
\cline { 2 - 6 } & S1 & S2 & S3 & M3 & S11 & S21 \\
\hline Agneta & 85 & 11 & 0 & 62 & 55 & 8 \\
Arra & 79 & 33 & 0 & 99 & 89 & 3 \\
Hja 673 & 83 & 65 & 3 & 93 & 78 & 19 \\
Pomo & 86 & 51 & 0 & 73 & 71 & 5 \\
\hline
\end{tabular}

$\mathrm{S} 1=\%$ of seedlings with the first tiller

$\mathrm{S} 2=\%$ of seedlings with the second tiller

$\mathrm{S} 3=\%$ of seedlings with the third tiller

M3 $=\%$ of the main shoots with the third fully opened leaf

$\mathrm{S} 11=\%$ of the first tillers with the first fully opened leaf

S21 $=\%$ of the second tillers with the first fully opened leaf ing time there were 1.2 times more $(p=0.09)$ generative tillers in the stand of the variety $\mathrm{Hja}$ 673 than in other stands (data not given). The ratio of actual number of heads of each mixture to expected number approached one $(0.95$ to 1.05 ) by the end of the heading (data not given).

\section{Actual and expected grain yields}

The results showed clearly that the overall effect of the number of components in the mixture on the grain yield was poor (Table 5). Two-variety mixtures yielded $0.4 \%$ and threevariety mixtures $1.7 \%$ more whereas, fourvariety mixtures yielded $0.5 \%$ less than the mean yield of the varieties grown in pure stands.

The calculated mean yields over the years 1983 to 1985 showed that no statistically significant $(p>0.05)$ differences between the yields of mixtures existed, whereas the yields of monocultures differed from each other $(p<0.05)$ (Table 5). The yield of Pomo varied the most as determined by the coefficient of variation (Table 5). The yield of the mixture of Agneta, Arra and $\mathrm{Hja} 673$ was the most stable.

In general, the yield of a mixture was between the yields of the components grown in pure stand. Overyielding of some mixtures took place, but the difference was not statistically significant.

In every year the actual yields of the mixtures correlated with the expected yields of the mixtures (1983 r $=0.841^{* *}, 1984 \mathrm{r}=0.672^{*}$ 
Table 5. The grain yield $(\mathrm{kg} / \mathrm{ha})$ of monocultures and mixtures of barley cultivars in $1983-1985$. A/E is of the ratio the actual and expected yield of the mixtures. $\mathrm{CV}=$ Coefficient of variation of grain yields (all the yields in groups are included, e.g. in monocultures $\mathrm{N}=12$ etc.). Grain yield means in year columns, grain yield means in the average column and grain yield means in the average row followed by the same letter are not significantly different at the $5 \%$ level (HSD test).

\begin{tabular}{|c|c|c|c|c|c|c|c|c|c|}
\hline \multirow{3}{*}{ Stand } & \multicolumn{6}{|c|}{ Year } & \multirow{2}{*}{\multicolumn{2}{|c|}{ Average }} & \multirow[b]{3}{*}{$\mathrm{CV}$} \\
\hline & \multicolumn{2}{|c|}{1983} & \multicolumn{2}{|c|}{1984} & \multicolumn{2}{|c|}{1985} & & & \\
\hline & Grain yield & $\mathrm{A} / \mathrm{E}$ & Grain yield & $\mathrm{A} / \mathrm{E}$ & Grain yield & $\mathrm{A} / \mathrm{E}$ & Grain yield & $\mathrm{A} / \mathrm{E}$ & \\
\hline Agneta(Ag) & $4752 \mathrm{bc}$ & & $5613 \mathrm{bc}$ & & 4508 bcde & & 4958 b & & 9.6 \\
\hline Arra (Ar) & $4679 a b c$ & & $5212 \mathrm{ab}$ & & 4540 bcde & & $4810 a b$ & & 6.0 \\
\hline Hja673 $(\mathrm{Hj})$ & $4276 \mathrm{a}$ & & $5618 \mathrm{bc}$ & & $4716 \mathrm{de}$ & & $4870 \mathrm{ab}$ & & 11.5 \\
\hline Pomo (Po) & $4560 \mathrm{abc}$ & & $5369 \mathrm{abc}$ & & $3608 \mathrm{a}$ & & 4512 a & & 16.0 \\
\hline $\mathrm{AgAr}$ & $4865 \mathrm{c}$ & 103 & $5299 \mathrm{abc}$ & 98 & 4440 bcde & 98 & $4868 \mathrm{ab}$ & 100 & 7.2 \\
\hline $\mathrm{AgHj}$ & $4611 \mathrm{abc}$ & 102 & $5691 \mathrm{c}$ & 101 & 4618 bcde & 100 & 4973 b & 101 & 10.2 \\
\hline $\mathrm{AgPo}$ & $4735 \mathrm{bc}$ & 102 & 5554 bc & 101 & 4349 bcd & 107 & $4879 a b$ & 103 & 10.3 \\
\hline $\mathrm{ArHj}$ & $4590 \mathrm{abc}$ & 103 & $5457 \mathrm{abc}$ & 101 & 4430 bcde & 95 & $4825 \mathrm{ab}$ & 100 & 9.4 \\
\hline ArPo & $4761 \mathrm{bc}$ & 103 & 5049 a & 95 & $4303 \mathrm{bc}$ & 106 & $4704 \mathrm{ab}$ & 101 & 6.5 \\
\hline $\mathrm{HjPo}$ & $4369 \mathrm{ab}$ & 99 & $5244 \mathrm{ab}$ & 95 & $4154 \mathrm{~b}$ & 100 & $4589 \mathrm{ab}$ & 98 & 10.3 \\
\hline $\mathrm{AgArHj}$ & $4767 \mathrm{bc}$ & 104 & $5273 \mathrm{ab}$ & 96 & $4787 \mathrm{e}$ & 104 & 4942 b & 101 & 4.7 \\
\hline AgArPo & $4796 \mathrm{c}$ & 103 & $5570 \mathrm{bc}$ & 103 & $4274 \mathrm{bc}$ & 101 & $4880 \mathrm{ab}$ & 102 & 10.9 \\
\hline $\mathrm{AgHjPo}$ & 4692 bc & 104 & $5528 \mathrm{bc}$ & 100 & $4300 \mathrm{bc}$ & 101 & $4840 \mathrm{ab}$ & 102 & 10.6 \\
\hline $\mathrm{ArHjPo}$ & $4646 \mathrm{abc}$ & 103 & $5598 \mathrm{bc}$ & 104 & $4196 \mathrm{~b}$ & 98 & $4813 a b$ & 101 & 12.1 \\
\hline $\mathrm{AgArHjPo}$ & $4502 \mathrm{abc}$ & 99 & $5579 \mathrm{bc}$ & 102 & $4206 \mathrm{~b}$ & 97 & $4762 \mathrm{ab}$ & 99 & 12.4 \\
\hline Average & $4640 \mathrm{a}$ & & $5453 \mathrm{~b}$ & & 4362 a & & 4815 & & \\
\hline Mono & 4567 & 100 & 5453 & 100 & 4343 & 100 & 4788 & 100 & 11.7 \\
\hline 2-mixture & 4655 & 102 & 5382 & 99 & 4382 & 101 & 4806 & 100 & 9.5 \\
\hline 3-mixture & 4725 & 103 & 5492 & 101 & 4389 & 101 & 4869 & 102 & 10.0 \\
\hline 4-mixture & 4502 & 99 & 5579 & 102 & 4206 & 97 & 4762 & 99 & 12.4 \\
\hline
\end{tabular}

and $\left.1985 \mathrm{r}=0.703^{*}\right)$. Examination of the ratio between the actual and the expected yields of two- and three-variety mixtures revealed that the ratio was more likely to be above one (55\% of the two- and $75 \%$ of the three-variety mixtures) than under one (33\% of the two-and $17 \%$ of the three-variety mixtures). The actual yield of the four-variety mixture was lower than expected in two cases out of three.

\section{The relative yields $(R Y)$ and the relative yield totals ( $R Y T)$}

The relative yield of the variety should be 0.50 in two-variety, 0.33 in three-variety and 0.25 in four-variety mixtures if they occupy the same space in the mixture as in the monoculture. The variety Arra was always able to occupy more space in mixtures than in monocultures (Tables 6, 7 and 8). Also the relative yields of Arra varied the least. In general, Hja 673 occupied less space in mixtures than in monocultures. In 1985, however, the relative yields of $\mathrm{Hja} 673$ exceeded the expected in some mixtures. The relative yields of Agneta and Pomo fluctuated above and below the expected value.

In two-variety mixtures the correlation $(\mathrm{RYj}$ $>$ RYi) between the increase and decrease of the relative yields of the components was obvious $\left(\mathrm{r}=-0.792^{* * *}\right.$, $\left.\mathrm{df}=16\right)$. In threevariety mixtures the correlation $(\mathrm{RYj}>\mathrm{RYi}$ $>\mathrm{RYz}$ ) between the increase and the decrease of the relative yields of the components was not clearly explicable $(\mathrm{RYj} / \mathrm{RYz} \mathrm{r}=-0.311$ ns, $\quad$ RYj/RYi r $=-0.322$ ns, RYi/RYz $\mathrm{r}=-0.470 \mathrm{~ns})$.

The relative yield total of a given mixture was close to one (Table 9). The relative yield total of $55 \%$ of two-variety mixtures and $67 \%$ 
Table 6. Relative yields of different barley varieties grown in two-variety mixtures in $1983-1985$. CV $=$ coefficient of variation due to the year $(\mathrm{y})$ and the mixtures $(\mathrm{m})$.

\begin{tabular}{|c|c|c|c|c|c|c|c|c|}
\hline \multirow[b]{2}{*}{ Variety } & \multirow[b]{2}{*}{ Year } & \multicolumn{4}{|c|}{ Component in the mixture } & \multirow[b]{2}{*}{ Average } & \multirow[b]{2}{*}{$\mathrm{CV}(\mathrm{y})$} & \multirow[b]{2}{*}{$\mathrm{CV}(\mathrm{m})$} \\
\hline & & $\mathrm{Ag}$ & $\mathrm{Ar}$ & $\mathrm{Hj}$ & Po & & & \\
\hline Agneta & 1983 & & 0.37 & 0.57 & 0.46 & 0.47 & & \\
\hline \multirow[t]{3}{*}{$(\mathrm{Ag})$} & 1984 & & 0.39 & 0.58 & 0.58 & 0.52 & & \\
\hline & 1985 & & 0.37 & 0.45 & 0.52 & 0.45 & & \\
\hline & Average & & 0.38 & 0.53 & 0.52 & 0.48 & 6.1 & 14.3 \\
\hline Arra & 1983 & 0.67 & & 0.66 & 0.57 & 0.63 & & \\
\hline \multirow[t]{3}{*}{ (Ar) } & 1984 & 0.59 & & 0.67 & 0.62 & 0.63 & & \\
\hline & 1985 & 0.61 & & 0.58 & 0.60 & 0.60 & & \\
\hline & Average & 0.62 & & 0.64 & 0.60 & 0.62 & 2.3 & 2.6 \\
\hline Hјa 673 & 1983 & 0.45 & 0.36 & & 0.37 & 0.39 & & \\
\hline \multirow{3}{*}{$(\mathrm{Hj})$} & 1984 & 0.43 & 0.35 & & 0.46 & 0.41 & & \\
\hline & 1985 & 0.55 & 0.38 & & 0.52 & 0.48 & & \\
\hline & Average & 0.48 & 0.36 & & 0.45 & 0.43 & 9.0 & 11.9 \\
\hline \multirow{4}{*}{$\begin{array}{l}\text { Pomo } \\
\text { (Po) }\end{array}$} & 1983 & 0.55 & 0.45 & 0.60 & & 0.53 & & \\
\hline & 1984 & 0.43 & 0.34 & 0.49 & & 0.42 & & \\
\hline & 1985 & 0.55 & 0.44 & 0.47 & & 0.47 & & \\
\hline & Average & 0.51 & 0.41 & 0.52 & & 0.48 & 9.5 & 10.3 \\
\hline
\end{tabular}

Table 7. Relative yields of different barley varieties grown in three-variety mixtures in $1983-1985 . \mathrm{CV}=$ coefficient of variation due to the years $(y)$ and the mixtures $(\mathrm{m})$.

\begin{tabular}{|c|c|c|c|c|c|c|c|c|c|c|}
\hline \multirow[b]{2}{*}{ Variety } & \multirow[b]{2}{*}{ Year } & \multicolumn{6}{|c|}{ Components in the mixture } & \multirow[b]{2}{*}{ Average } & \multirow[b]{2}{*}{$\mathrm{CV}(\mathrm{y})$} & \multirow[b]{2}{*}{$\mathrm{CV}(\mathrm{m})$} \\
\hline & & $\begin{array}{l}\mathrm{Ar} \\
\mathrm{Hj}\end{array}$ & $\begin{array}{l}\mathrm{Ar} \\
\mathrm{Po}\end{array}$ & $\begin{array}{l}\mathrm{Hj} \\
\mathrm{Po}\end{array}$ & $\begin{array}{l}\mathrm{Ag} \\
\mathrm{Hj}\end{array}$ & $\begin{array}{l}\mathrm{Ag} \\
\mathrm{Po}\end{array}$ & $\begin{array}{l}\mathrm{Ag} \\
\mathrm{Ar}\end{array}$ & & & \\
\hline Agneta & 1983 & 0.30 & 0.32 & 0.34 & & & & 0.32 & & \\
\hline \multirow[t]{4}{*}{$(\mathrm{Ag})$} & 1984 & 0.32 & 0.33 & 0.39 & & & & 0.35 & & \\
\hline & 1985 & 0.30 & 0.27 & 0.28 & & & & 0.28 & & \\
\hline & Average & 0.31 & 0.31 & 0.34 & & & & 0.32 & 9.0 & 4.4 \\
\hline & 1983 & & & 0.44 & 0.49 & 0.41 & & 0.45 & & \\
\hline Arra & 1984 & & & 0.50 & 0.42 & 0.47 & & 0.46 & & \\
\hline \multirow[t]{3}{*}{ (Ar) } & 1985 & & & 0.41 & 0.45 & 0.44 & & 0.43 & & \\
\hline & Average & & & 0.45 & 0.45 & 0.44 & & 0.45 & 2.8 & 1.0 \\
\hline & 1983 & & 0.22 & & & 0.26 & 0.25 & 0.24 & & \\
\hline Hјa 673 & 1984 & & 0.28 & & & 0.29 & 0.23 & 0.27 & & \\
\hline \multirow[t]{3}{*}{$(\mathrm{Hj})$} & 1985 & & 0.29 & & & 0.39 & 0.30 & 0.33 & & \\
\hline & Average & & 0.26 & & & 0.31 & 0.26 & 0.28 & 13.4 & 8.4 \\
\hline & 1983 & 0.35 & & & 0.42 & & 0.28 & 0.35 & & \\
\hline Pomo & 1984 & 0.26 & & & 0.31 & & 0.26 & 0.28 & & \\
\hline \multirow[t]{2}{*}{ (Po) } & 1985 & 0.28 & & & 0.32 & & 0.30 & 0.30 & & \\
\hline & Average & 0.30 & & & 0.35 & & 0.28 & 0.31 & 9.5 & 9.5 \\
\hline
\end{tabular}


Table 8. Relative yields of different barley varieties grown in four-variety mixtures in $1983-85 . \mathrm{CV}=$ coefficient of variation due to the years.

\begin{tabular}{lccccr}
\hline Variety & \multicolumn{5}{c}{ Year } \\
\cline { 2 - 4 } & 1983 & 1984 & 1985 & Average & CV \\
\hline Agneta & 0.24 & 0.28 & 0.16 & 0.23 & 21.7 \\
Arra & 0.33 & 0.36 & 0.34 & 0.34 & 3.7 \\
Hja 673 & 0.17 & 0.20 & 0.23 & 0.20 & 12.3 \\
Pomo & 0.23 & 0.19 & 0.23 & 0.22 & 8.6 \\
\hline
\end{tabular}

of three-variety mixtures was above one. In one case out of three the relative yield total of the four-variety mixture was above one. It is important to note that in the three successive years any individual variety did not consistently contribute positively or negatively to the relative yield totals of all its mixtures.

\section{Competitive ratio (CR)}

The results presented in Tables 10, 11 and 12 show clearly that the earliest variety Arra was the most dominant variety $(C R>1)$. The competitive ratio of Arra was the most stable
Table 9. The relative yield totals of barley variety mixtures in 1983-1985. $(\mathrm{Ag}=\mathrm{Agneta}, \mathrm{Ar}=\mathrm{Arra}, \mathrm{Po}=\mathrm{Pomo}$, $\mathrm{Hj}=\mathrm{Hja}$ 673)

\begin{tabular}{lcccc}
\hline Mixture & \multicolumn{3}{c}{ Year } & \\
\cline { 2 - 4 } & 1983 & 1984 & 1985 & Average \\
\hline $\mathrm{AgAr}$ & 1.04 & 0.98 & 0.98 & 1.00 \\
$\mathrm{AgHj}$ & 1.02 & 1.01 & 1.00 & 1.01 \\
$\mathrm{AgPo}$ & 1.01 & 1.01 & 1.07 & 1.03 \\
$\mathrm{ArHj}$ & 1.02 & 1.02 & 0.96 & 1.00 \\
$\mathrm{ArPo}$ & 1.02 & 0.96 & 1.04 & 1.01 \\
$\mathrm{HjPo}$ & 0.97 & 0.95 & 0.99 & 0.97 \\
$\mathrm{AgArHj}$ & 1.04 & 0.97 & 1.05 & 1.02 \\
$\mathrm{AgArPo}$ & 1.01 & 1.06 & 1.01 & 1.03 \\
$\mathrm{AgHjPo}$ & 1.02 & 0.99 & 0.99 & 1.00 \\
ArHjPo & 1.01 & 1.04 & 0.98 & 1.01 \\
AgArHjPo & 0.97 & 1.03 & 0.96 & 0.99 \\
\hline Average & 1.01 & 1.00 & 1.00 & 1.00 \\
2-mixture & 1.01 & 0.99 & 1.01 & 1.00 \\
3-mixture & 1.02 & 1.02 & 1.01 & 1.02 \\
4-mixture & 0.97 & 1.03 & 0.96 & 0.99 \\
\hline
\end{tabular}

compared to other varieties (Table 13). The other early variety $\mathrm{Hja} 673$ was in general the subordinate one. However, in $1985 \mathrm{Hja} 673$ was equal to or more competitive than Agneta or Pomo. The competitive relationship be-

Table 10. Competitive ratio of different barley varieties grown in two-variety mixtures in $1983-1985$.

\begin{tabular}{|c|c|c|c|c|c|c|}
\hline \multirow[b]{2}{*}{ Variety } & \multirow[b]{2}{*}{ Year } & \multicolumn{4}{|c|}{ Component in the mixture } & \multirow[b]{2}{*}{ Average } \\
\hline & & $\mathrm{Ag}$ & $\mathrm{Ar}$ & $\mathrm{Hj}$ & Po & \\
\hline Agneta & 1983 & & 0.55 & 1.26 & 0.83 & 0.88 \\
\hline \multirow[t]{3}{*}{$(\mathrm{Ag})$} & 1984 & & 0.66 & 1.35 & 1.35 & 1.12 \\
\hline & 1985 & & 0.61 & 0.82 & 0.95 & 0.79 \\
\hline & Average & & 0.61 & 1.14 & 1.04 & 0.93 \\
\hline Arra & 1983 & 1.81 & & 1.83 & 1.26 & 1.65 \\
\hline \multirow[t]{3}{*}{ (Ar) } & 1984 & 1.51 & & 1.91 & 1.82 & 1.75 \\
\hline & 1985 & 1.65 & & 1.53 & 1.36 & 1.51 \\
\hline & Average & 1.67 & & 1.76 & 1.48 & 1.64 \\
\hline Hјa 673 & 1983 & 0.79 & 0.55 & & 0.62 & 0.65 \\
\hline \multirow{3}{*}{$(\mathrm{Hj})$} & 1984 & 0.74 & 0.52 & & 0.94 & 0.73 \\
\hline & 1985 & 1.22 & 0.66 & & 1.11 & 1.00 \\
\hline & Average & 0.84 & 0.58 & & 0.89 & 0.77 \\
\hline \multirow{4}{*}{$\begin{array}{l}\text { Pomo } \\
\text { (Po) }\end{array}$} & 1983 & 1.20 & 0.79 & 1.62 & & 1.20 \\
\hline & 1984 & 0.72 & 0.55 & 1.07 & & 0.79 \\
\hline & 1985 & 1.06 & 0.73 & 0.90 & & 0.90 \\
\hline & Average & 0.99 & 0.69 & 1.20 & & 0.96 \\
\hline
\end{tabular}


Table 11. Competitive ratio of different barley varieties grown in three-variety mixtures in 1983-1985.

\begin{tabular}{|c|c|c|c|c|c|c|c|c|c|c|c|c|c|c|}
\hline \multirow{5}{*}{$\begin{array}{l}\text { Variety } \\
\text { Agneta } \\
\text { (Ag) }\end{array}$} & \multirow{3}{*}{$\begin{array}{l}\text { Year } \\
1983\end{array}$} & \multicolumn{12}{|c|}{ Mixture } & \multirow{3}{*}{$\begin{array}{c}\text { Avg. } \\
0.96\end{array}$} \\
\hline & & \multicolumn{3}{|c|}{$\mathrm{Ag}-\mathrm{Ar}-\mathrm{Hj}$} & \multicolumn{3}{|c|}{$\mathrm{Ag}-\mathrm{Ar}-\mathrm{Po}$} & \multicolumn{3}{|c|}{$\mathrm{Ag}-\mathrm{Hj}-\mathrm{Po}$} & \multicolumn{3}{|c|}{$\mathrm{Ar}-\mathrm{Hj}-\mathrm{Po}$} & \\
\hline & & & 0.61 & 1.20 & & 0.70 & 1.14 & & 1.31 & 0.81 & & & & \\
\hline & 1984 & & 0.76 & 1.39 & & 0.70 & 1.27 & & 1.34 & 1.26 & & & & 1.12 \\
\hline & 1985 & & 0.67 & 1.00 & & 0.61 & 0.90 & & 0.72 & 0.88 & & & & 0.80 \\
\hline \multirow{4}{*}{$\begin{array}{l}\text { Arra } \\
(\mathrm{Ar})\end{array}$} & Average & & 0.68 & 1.20 & & 0.67 & 1.10 & & 1.12 & 0.98 & & & & 0.96 \\
\hline & 1983 & 1.63 & & 1.96 & 1.28 & & 1.45 & & & & & 2.00 & 1.26 & 1.60 \\
\hline & 1984 & 1.31 & & 1.83 & 1.42 & & 1.81 & & & & & 1.79 & 1.92 & 1.68 \\
\hline & 1985 & 1.50 & & 1.50 & 1.67 & & 1.47 & & & & & 1.41 & 1.46 & 1.50 \\
\hline \multirow{4}{*}{$\begin{array}{l}\mathrm{Hja} 673 \\
(\mathrm{Hj})\end{array}$} & Average & 1.48 & & 1.76 & 1.46 & & 1.58 & & & & & 1.73 & 1.55 & 1.59 \\
\hline & 1983 & 0.83 & 0.51 & & & & & 0.76 & & 0.62 & 0.50 & & 0.63 & 0.64 \\
\hline & 1984 & 0.72 & 0.55 & & & & & 0.74 & & 0.94 & 0.56 & & 1.06 & 0.76 \\
\hline & 1985 & 1.00 & 0.67 & & & & & 1.39 & & 1.22 & 0.71 & & 1.04 & 1.01 \\
\hline \multirow{5}{*}{$\begin{array}{l}\text { Pomo } \\
\text { (Po) }\end{array}$} & Average & 0.85 & 0.58 & & & & & 0.96 & & 0.93 & 0.59 & & 0.91 & 0.80 \\
\hline & 1983 & & & & 0.88 & 0.68 & & 1.24 & 1.62 & & 0.80 & 1.56 & & 1.13 \\
\hline & 1984 & & & & 0.79 & 0.55 & & 0.79 & 1.07 & & 0.56 & 1.08 & & 0.81 \\
\hline & 1985 & & & & 1.11 & 0.68 & & 1.14 & 0.82 & & 0.68 & 0.97 & & 0.90 \\
\hline & Average & & & & 0.93 & 0.64 & & 1.06 & 1.17 & & 0.68 & 1.20 & & 0.95 \\
\hline
\end{tabular}

tween the latest varieties Pomo and Agneta in a given year was rather constant irrespecwas rather inconsistent. In general, the rank tive of the number of components in the mixbetween the competitive ratio of the varieties ture.

Table 12. Competitive ratio of different barley varieties grown in four-variety mixtures in $1983-1985$.

\begin{tabular}{|c|c|c|c|c|c|c|}
\hline \multirow[b]{2}{*}{ Variety } & \multirow[b]{2}{*}{ Year } & \multicolumn{4}{|c|}{ Mixture } & \multirow[b]{2}{*}{ Average } \\
\hline & & $\mathrm{Ag}$ & $\mathrm{Ar}$ & $\mathrm{Hj}$ & Po & \\
\hline Agneta & 1983 & & 0.73 & 1.41 & 1.03 & 1.06 \\
\hline \multirow[t]{3}{*}{$(\mathrm{Ag})$} & 1984 & & 0.78 & 1.40 & 1.47 & 1.22 \\
\hline & 1985 & & 0.47 & 0.70 & 0.69 & 0.62 \\
\hline & Average & & 0.66 & 1.17 & 1.06 & 0.97 \\
\hline \multirow{4}{*}{$\begin{array}{l}\text { Arra } \\
\text { (Ar) }\end{array}$} & 1983 & 1.38 & & 1.94 & 1.43 & 1.58 \\
\hline & 1984 & 1.29 & & 1.80 & 1.89 & 1.66 \\
\hline & 1985 & 2.13 & & 1.48 & 1.48 & 1.70 \\
\hline & Average & 1.60 & & 1.74 & 1.60 & 1.65 \\
\hline \multirow{4}{*}{$\begin{array}{l}\mathrm{Hja} 673 \\
(\mathrm{Hj})\end{array}$} & 1983 & 0.71 & 0.52 & & 0.74 & 0.66 \\
\hline & 1984 & 0.71 & 0.56 & & 1.05 & 0.77 \\
\hline & 1985 & 1.44 & 0.68 & & 1.00 & 1.04 \\
\hline & Average & 0.95 & 0.59 & & 0.93 & 0.82 \\
\hline \multirow{4}{*}{$\begin{array}{l}\text { Pomo } \\
\text { (Po) }\end{array}$} & 1983 & 0.93 & 0.70 & 1.35 & & 0.99 \\
\hline & 1984 & 0.67 & 0.53 & 0.95 & & 0.72 \\
\hline & 1985 & 1.38 & 0.68 & 1.00 & & 1.02 \\
\hline & Average & 0.99 & 0.64 & 1.10 & & 0.91 \\
\hline
\end{tabular}


Table 13. The variation of competitive ratio of different barley varieties as determined by coefficient of variation (CV) due to the years (y) and the mixtures (m) in 1983-1985.

\begin{tabular}{llrr}
\hline Variety & Mixture & $\mathrm{CV}(\mathrm{y})$ & $\mathrm{CV}(\mathrm{m})$ \\
\hline \multirow{2}{*}{ Agneta } & two-variety & 15.0 & 24.7 \\
& three-variety & 13.6 & 21.9 \\
& four-variety & 26.2 & 22.8 \\
Arra & two-variety & 6.0 & 7.3 \\
& three-variety & 4.6 & 7.2 \\
& four-variety & 3.0 & 4.0 \\
Hja673 & two-variety & 22.6 & 17.6 \\
& three-variety & 19.3 & 19.7 \\
& four-variety & 19.5 & 20.2 \\
Pomo & two-variety & 18.0 & 21.8 \\
& three-variety & 14.2 & 23.8 \\
& four-variety & 14.8 & 21.6 \\
\hline
\end{tabular}

\section{Grain weight}

The environmental conditions in the mixtures reduced the grain weight of Agneta and
Hja 673 compared with their monocultures (data not shown). The grain weight of Arra was usually higher in mixtures than in monoculture. There was no relationship between the grain weight of Pomo whether grown in monoculture or in mixtures.

\section{The effect of the variety and the level of nitrogen fertilization (Exp.2)}

\section{Actual and expected grain yields}

Increasing nitrogen fertilization from 50 $\mathrm{kg} / \mathrm{ha}$ to $100 \mathrm{~kg} / \mathrm{ha}$ had a negative effect on the mean yield $(\mathrm{p}<0.05)$ (Table 14$)$. The average yield of the monocultures was the lowest. The average yield of the mixtures (two-, threeand four-variety mixtures) increased when the number of components in the stand increased. The yield of mixtures varied less than the yield of monocultures.

Table 14. The grain yield $(\mathrm{kg} / \mathrm{ha})$ of monocultures and mixtures of barley cultivars at two levels of nitrogen fertilization. $\mathrm{A} / \mathrm{E}$ is the ratio of the actual and expected yield of the mixtures. $\mathrm{CV}=$ Coefficient of variation of grain yields (all the yields in groups are included). Grain yield means in the average column and grain yield means in the average row followed by the same letter are not significantly different at the 5\% level (HSD test).

\begin{tabular}{|c|c|c|c|c|c|c|c|}
\hline \multirow[t]{3}{*}{ Stand } & \multicolumn{4}{|c|}{ Nitrogen fertilization (kg N/ha) } & & & \multirow[b]{3}{*}{$\mathrm{CV}$} \\
\hline & \multicolumn{2}{|c|}{50} & \multicolumn{2}{|c|}{100} & \multicolumn{2}{|c|}{ Average } & \\
\hline & Grain yield & $\mathrm{A} / \mathrm{E}$ & Grain yield & $\mathrm{A} / \mathrm{E}$ & Grain yield & $\mathrm{A} / \mathrm{E}$ & \\
\hline Agneta(Ag) & 5884 & & 5255 & & $5570 \mathrm{bc}$ & & \\
\hline Ida (Id) & 6058 & & 5417 & & $5738 \mathrm{c}$ & & \\
\hline Kustaa (Ku) & 6070 & & 5210 & & $5640 \mathrm{bc}$ & & \\
\hline Pomo (Po) & 3828 & & 3871 & & $3850 \mathrm{a}$ & & \\
\hline AgId & 5801 & 97 & 5800 & 109 & $5801 \mathrm{c}$ & 103 & \\
\hline $\mathrm{AgKu}$ & 6041 & 101 & 6040 & 115 & $6041 \mathrm{c}$ & 108 & \\
\hline $\mathrm{AgPo}$ & 5272 & 109 & 4842 & 106 & $5057 \mathrm{bc}$ & 107 & \\
\hline IdKu & 5679 & 94 & 5410 & 102 & $5545 \mathrm{bc}$ & 97 & \\
\hline IdPo & 5662 & 115 & 4878 & 105 & $5270 \mathrm{bc}$ & 110 & \\
\hline KuPo & 4848 & 98 & 4451 & 98 & $4650 \mathrm{ab}$ & 98 & \\
\hline AgIdKu & 6167 & 103 & 5801 & 110 & $5984 \mathrm{c}$ & 106 & \\
\hline AgIdPo & 5613 & 107 & 4967 & 103 & $5290 \mathrm{bc}$ & 105 & \\
\hline AgKuPo & 5044 & 96 & 5170 & 108 & $5107 \mathrm{bc}$ & 102 & \\
\hline IdKuPo & 5852 & 110 & 4934 & 102 & $5393 \mathrm{bc}$ & 106 & \\
\hline AgIdKuPo & 5832 & 107 & 5352 & 108 & $5592 \mathrm{bc}$ & 108 & \\
\hline Average & 5577 a & & $5160 \mathrm{~b}$ & & 5370 & & \\
\hline Mono & 5460 & 100 & 4938 & 100 & 5199 & 100 & 16.2 \\
\hline 2-mixture & 5551 & 102 & 5237 & 106 & 5394 & 104 & 9.4 \\
\hline 3-mixture & 5669 & 104 & 5218 & 106 & 5444 & 105 & 8.1 \\
\hline 4-mixture & 5832 & 107 & 5352 & 108 & 5592 & 108 & 4.3 \\
\hline
\end{tabular}


The yield of a given mixture was usually between the monoculture yields of the components. The overyielding which occurred was not statistically significant. The correlation between the actual yields and the expected yields was obvious $(\mathrm{r}=0.802 * * *, \mathrm{df}=20)$.

The ratio of the actual to the expected yields of mixtures was more frequently above one $(67 \% \mathrm{n}=12$ of the two- and $87 \% \mathrm{n}=8$ of the three-variety mixtures) than below one $(33 \%$

Table 15. Relative yields of different barley varieties grown in two-variety mixtures at two levels of nitrogen fertilization. $\mathrm{CV}=$ coefficient of variation due to the nitrogen fertilization $(\mathrm{n})$ and the mixtures $(\mathrm{m})$.

\begin{tabular}{|c|c|c|c|c|c|c|c|c|}
\hline \multirow[b]{2}{*}{ Variety } & \multirow[b]{2}{*}{$\begin{array}{l}\text { Nitrogen } \\
\text { (kg N/ha) }\end{array}$} & \multicolumn{4}{|c|}{ Component in the mixture } & \multirow[b]{2}{*}{ Average } & \multirow[b]{2}{*}{$\mathrm{CV}(\mathrm{m})$} & \multirow[b]{2}{*}{$\mathrm{CV}(\mathrm{n})$} \\
\hline & & $\mathrm{Ag}$ & Id & $\mathrm{Ku}$ & Po & & & \\
\hline Agneta & 50 & & 0.52 & 0.61 & 0.57 & 0.57 & & \\
\hline \multirow[t]{2}{*}{ (Ag) } & 100 & & 0.65 & 0.67 & 0.59 & 0.64 & & \\
\hline & Average & & 0.59 & 0.64 & 0.58 & 0.60 & 4.4 & 5.8 \\
\hline Ida & 50 & 0.45 & & 0.47 & 0.57 & 0.50 & & \\
\hline \multirow[t]{2}{*}{ (Id) } & 100 & 0.44 & & 0.54 & 0.53 & 0.50 & & \\
\hline & Average & 0.45 & & 0.51 & 0.55 & 0.50 & 8.2 & 0.0 \\
\hline $\begin{array}{l}\text { Kustaa } \\
(\mathrm{Ku})\end{array}$ & 50 & 0.41 & 0.47 & & 0.50 & 0.46 & & \\
\hline \multirow[t]{2}{*}{$(\mathrm{Ku})$} & 100 & 0.49 & 0.48 & & 0.47 & 0.48 & & \\
\hline & Average & 0.45 & 0.48 & & 0.49 & 0.47 & 3.6 & 2.1 \\
\hline \multirow{3}{*}{$\begin{array}{l}\text { Pomo } \\
\text { (Po) }\end{array}$} & 50 & 0.50 & 0.58 & 0.48 & & 0.52 & & \\
\hline & 100 & 0.45 & 0.53 & 0.53 & & 0.50 & & \\
\hline & Average & 0.48 & 0.56 & 0.51 & & 0.52 & 6.4 & 1.9 \\
\hline
\end{tabular}

Table 16. Relative yields of different barley varieties grown in three-variety mixtures at two levels of nitrogen fertilization. $\mathrm{CV}=$ coefficient of variation due to the nitrogen fertilization $(\mathrm{n})$ and the mixtures $(\mathrm{m})$.

\begin{tabular}{|c|c|c|c|c|c|c|c|c|c|c|}
\hline \multirow[b]{2}{*}{ Variety } & \multirow[b]{2}{*}{$\begin{array}{l}\text { Nitrogen } \\
(\mathrm{kg} \mathrm{N} / \mathrm{ha})\end{array}$} & \multicolumn{6}{|c|}{ Components in the mixture } & \multirow[b]{2}{*}{ Average } & \multirow[b]{2}{*}{$\mathrm{CV}(\mathrm{m})$} & \multirow[b]{2}{*}{$\mathrm{CV}(\mathrm{n})$} \\
\hline & & $\begin{array}{l}\text { Id } \\
\mathrm{Ku}\end{array}$ & $\begin{array}{l}\text { Id } \\
\text { Po }\end{array}$ & $\begin{array}{l}\mathrm{Ku} \\
\mathrm{Po}\end{array}$ & $\begin{array}{l}\mathrm{Ag} \\
\mathrm{Ku}\end{array}$ & $\begin{array}{l}\mathrm{Ag} \\
\mathrm{Po}\end{array}$ & $\begin{array}{l}\mathrm{Ag} \\
\mathrm{Id}\end{array}$ & & & \\
\hline Agneta & 50 & 0.43 & 0.41 & 0.36 & & & & 0.40 & & \\
\hline \multirow[t]{2}{*}{$(\mathrm{Ag})$} & 100 & 0.48 & 0.43 & 0.45 & & & & 0.45 & & \\
\hline & Average & 0.46 & 0.42 & 0.41 & & & & 0.43 & 8.5 & 5.8 \\
\hline \multirow[t]{2}{*}{ (Id) } & $\begin{array}{r}50 \\
100\end{array}$ & & & $\begin{array}{l}0.37 \\
0.37\end{array}$ & $\begin{array}{l}0.33 \\
0.30\end{array}$ & $\begin{array}{l}0.30 \\
0.29\end{array}$ & & $\begin{array}{l}0.33 \\
0.32\end{array}$ & & \\
\hline & Average & & & 0.37 & 0.32 & 0.30 & & 0.33 & 8.9 & 1.5 \\
\hline$(\mathrm{Ku})$ & $\begin{array}{r}50 \\
100\end{array}$ & & $\begin{array}{l}0.36 \\
0.31\end{array}$ & & & $\begin{array}{l}0.26 \\
0.29\end{array}$ & $\begin{array}{l}0.27 \\
0.32\end{array}$ & $\begin{array}{l}0.30 \\
0.31\end{array}$ & & \\
\hline $\begin{array}{l}\text { Pomo } \\
\text { (Po) }\end{array}$ & $\begin{array}{c}\text { Average } \\
50 \\
100\end{array}$ & $\begin{array}{l}0.37 \\
0.33\end{array}$ & 0.34 & & $\begin{array}{l}0.35 \\
0.34\end{array}$ & 0.28 & $\begin{array}{l}0.30 \\
0.36 \\
0.30\end{array}$ & $\begin{array}{l}0.31 \\
0.36 \\
0.32\end{array}$ & 8.1 & 1.6 \\
\hline (Po) & Average & 0.36 & & & 0.35 & & 0.33 & 0.35 & 3.6 & 5.7 \\
\hline
\end{tabular}


Table 17. Relative yields of different barley varieties grown in four-variety mixture at two levels of nitrogen fertilization. $\mathrm{CV}=$ coefficient of variation due to the level of nitrogen fertilization.

\begin{tabular}{lcccc}
\hline Variety & \multicolumn{3}{c}{$\begin{array}{c}\text { Nitrogen fertilization } \\
\text { (kg N/ha) }\end{array}$} \\
\cline { 2 - 4 } & 50 & 100 & Average & CV \\
\hline Agneta & 0.33 & 0.35 & 0.34 & 2.9 \\
Ida & 0.21 & 0.25 & 0.23 & 8.7 \\
Kustaa & 0.25 & 0.23 & 0.24 & 4.2 \\
Pomo & 0.29 & 0.25 & 0.27 & 7.4 \\
\hline
\end{tabular}

of the two-and $17 \%$ of the three-variety mixtures). It is important to note that the actual yields were usually higher than expected more frequently at low yielding conditions (i.e. at high nitrogen level) than at high yielding conditions (Table 14).

The relative yields $(R Y)$ and the relative yield totals (RYT)

The six-row variety Agneta occupied more space in all the mixtures than in monoculture (Tables 15, 16 and 17). Increasing nitrogen fertilization intensified the use of the space by Agneta. The two-row variety Kustaa was
Table 18. The relative yield totals of barley variety mixtures at two levels of nitrogen fertilization $(\mathrm{Ag}=\mathrm{Agneta}$, $\mathrm{Po}=\mathrm{Pomo}, \mathrm{Id}=\mathrm{Ida}, \mathrm{Ku}=\mathrm{Kustaa}$ ).

\begin{tabular}{lccc}
\hline \multirow{2}{*}{ Stand } & \multicolumn{3}{c}{ Nitrogen fertilization (kg N/ha) } \\
\cline { 2 - 4 } & 50 & 100 & Average \\
\hline AgId & 0.97 & 1.09 & 1.03 \\
AgKu & 1.01 & 1.15 & 1.08 \\
AgPo & 1.07 & 1.04 & 1.06 \\
IdKu & 0.94 & 1.02 & 0.98 \\
IdPo & 1.15 & 1.05 & 1.10 \\
KuPo & 0.98 & 0.99 & 0.99 \\
AgIdKu & 1.03 & 1.10 & 1.07 \\
AgIdPo & 1.07 & 1.02 & 1.05 \\
AgKuPo & 0.97 & 1.08 & 1.03 \\
IdKuPo & 1.10 & 1.02 & 1.06 \\
AgIdKuPo & 1.08 & 1.08 & 1.08 \\
\hline Average & 1.03 & 1.06 & 1.04 \\
2-mixture & 1.02 & 1.06 & 1.04 \\
3-mixture & 1.04 & 1.06 & 1.05 \\
4-mixture & 1.08 & 1.08 & 1.08 \\
\hline
\end{tabular}

usually able to use the space less efficiently in mixtures than in monoculture. The relative yields of the six-row variety Pomo and the two-row variety Ida varied both above and below the expected value.

The reader should observe that at the high nitrogen level almost all the relative yield to-

Table 19. Competitive ratio of different barley varieties grown in two-variety mixtures at two levels of nitrogen fertilization $(\mathrm{kgN} / \mathrm{ha})$.

\begin{tabular}{|c|c|c|c|c|c|c|}
\hline \multirow[t]{2}{*}{ Variety } & \multirow[t]{2}{*}{ Nitrogen } & \multicolumn{4}{|c|}{ Component in the mixture } & \multirow[b]{2}{*}{ Average } \\
\hline & & $\mathrm{Ag}$ & Id & $\mathrm{Ku}$ & Po & \\
\hline Agneta & 50 & & 1.15 & 1.49 & 1.14 & 1.26 \\
\hline \multirow[t]{2}{*}{$(\mathrm{Ag})$} & 100 & & 1.49 & 1.38 & 1.31 & 1.39 \\
\hline & Average & & 1.32 & 1.44 & 1.23 & 1.33 \\
\hline Ida & 50 & 0.87 & & 1.00 & 0.99 & 0.95 \\
\hline \multirow[t]{2}{*}{ (Id) } & 100 & 0.67 & & 1.14 & 1.00 & 0.94 \\
\hline & Average & 0.77 & & 1.07 & 0.96 & 0.95 \\
\hline Kustaa & 50 & 0.67 & 1.00 & & 1.02 & 0.90 \\
\hline \multirow[t]{2}{*}{$(\mathrm{Ku})$} & 100 & 0.72 & 0.88 & & 0.89 & 0.83 \\
\hline & Average & 0.70 & 0.94 & & 0.96 & 0.87 \\
\hline Pomo & 50 & 0.88 & 1.01 & 0.98 & & 0.96 \\
\hline \multirow[t]{2}{*}{ (Po) } & 100 & 0.77 & 1.00 & 1.13 & & 0.97 \\
\hline & Average & 0.83 & 1.01 & 1.06 & & 0.97 \\
\hline
\end{tabular}


tals were greater than one (Table 18). At low level of nitrogen fertilization $50 \%$ of the two-, $75 \%$ of the three-variety mixtures and the four-variety mixture had an advantage over monocultures (RYT $>1$ ).

\section{Competitive ratio (CR)}

The six-row variety Agneta was the domi- nant component in all the mixtures $(C R>1)$ (Tables 19, 20 and 21). The competitive ratio of Agneta was also the most stable in different mixtures compared to other varieties (Table 22). The dominance of Agneta usually increased as nitrogen fertilization increased. Almost without exception the two-row variety Kustaa was the subordinate variety. The com-

Table 20. Competitive ratio of different barley varieties grown in three-variety mixtures at two levels of nitrogen fertilization (kgN/ha).

\begin{tabular}{|c|c|c|c|c|c|c|c|c|c|c|c|c|c|c|}
\hline \multirow{4}{*}{$\begin{array}{l}\text { Variety } \\
\text { Agneta } \\
\text { (Ag) }\end{array}$} & \multirow{4}{*}{$\begin{array}{r}\mathrm{N} \\
50 \\
100\end{array}$} & \multicolumn{12}{|c|}{ Mixture } & \multirow{3}{*}{$\frac{\text { Avg. }}{1.30}$} \\
\hline & & \multicolumn{3}{|c|}{$\mathrm{Ag}-\mathrm{Id}-\mathrm{Ku}$} & \multicolumn{3}{|c|}{$\mathrm{Ag}-\mathrm{Id}-\mathrm{Po}$} & \multicolumn{3}{|c|}{$\mathrm{Ag}-\mathrm{Ku}-\mathrm{Po}$} & \multicolumn{3}{|c|}{$\mathrm{Id}-\mathrm{Ku}-\mathrm{Po}$} & \\
\hline & & & 1.28 & 1.61 & & 1.35 & 1.13 & & 1.41 & 1.03 & & & & \\
\hline & & & 1.59 & 1.48 & & 1.50 & 1.44 & & 1.55 & 1.30 & & & & 1.48 \\
\hline & Average & & 1.44 & 1.55 & & 1.43 & 1.30 & & 1.48 & 1.17 & & & & 1.40 \\
\hline Ida & 50 & 0.78 & & 1.25 & 0.74 & & 0.84 & & & & & 1.01 & 0.98 & 0.93 \\
\hline \multirow[t]{2}{*}{ (Id) } & 100 & 0.63 & & 0.93 & 0.67 & & 0.96 & & & & & 1.20 & 1.13 & 0.92 \\
\hline & Average & 0.71 & & 1.09 & 0.71 & & 0.90 & & & & & 1.11 & 1.06 & 0.93 \\
\hline Kustaa & 50 & 0.62 & 0.80 & & & & & 0.71 & & 0.73 & 0.99 & & 0.97 & 0.80 \\
\hline \multirow[t]{2}{*}{$(\mathrm{Ku})$} & 100 & 0.68 & 1.07 & & & & & 0.65 & & 0.84 & 0.83 & & 0.94 & 0.84 \\
\hline & Average & 0.65 & 0.94 & & & & & 0.68 & & 0.79 & 0.91 & & 0.96 & 0.82 \\
\hline \multirow{3}{*}{$(\mathrm{Po})$} & 50 & & & & 0.88 & 1.20 & & 0.97 & 1.37 & & 1.02 & 1.03 & & 1.08 \\
\hline & 100 & & & & 0.70 & 1.05 & & 0.77 & 1.19 & & 0.89 & 1.06 & & 0.94 \\
\hline & Average & & & & 0.79 & 1.13 & & 0.87 & 1.28 & & 0.96 & 1.05 & & 1.01 \\
\hline
\end{tabular}

Table 21. Competitive ratio of different barley varieties grown in four-variety mixtures at two levels of nitrogen fertilization $(\mathrm{kgN} / \mathrm{ha})$.

\begin{tabular}{|c|c|c|c|c|c|c|}
\hline \multirow[t]{2}{*}{ Variety } & \multirow[t]{2}{*}{ Nitrogen } & \multirow[b]{2}{*}{$\mathrm{Ag}$} & \multicolumn{3}{|c|}{ Component in the mixture } & \multirow[b]{2}{*}{ Average } \\
\hline & & & Id & $\mathrm{Ku}$ & Po & \\
\hline Agneta & 50 & & 1.55 & 1.27 & 1.12 & 1.31 \\
\hline \multirow[t]{2}{*}{$(\mathrm{Ag})$} & 100 & & 1.41 & 1.51 & 1.46 & 1.46 \\
\hline & Average & & 1.48 & 1.39 & 1.29 & 1.39 \\
\hline Ida & 50 & 0.64 & & 0.82 & 0.72 & 0.72 \\
\hline \multirow[t]{2}{*}{ (Id) } & 100 & 0.70 & & 1.06 & 1.03 & 0.93 \\
\hline & Average & 0.67 & & 0.94 & 0.88 & 0.83 \\
\hline Kustaa & 50 & 0.78 & 1.21 & & 0.87 & 0.95 \\
\hline \multirow[t]{2}{*}{$(\mathrm{Ku})$} & 100 & 0.66 & 0.94 & & 0.96 & 0.85 \\
\hline & Average & 0.72 & 1.08 & & 0.92 & 0.90 \\
\hline \multirow{3}{*}{$\begin{array}{l}\text { Pomo } \\
\text { (Po) }\end{array}$} & 50 & 0.88 & 1.38 & 1.13 & & 1.13 \\
\hline & 100 & 0.68 & 0.96 & 1.03 & & 0.89 \\
\hline & Average & 0.78 & 1.17 & 1.08 & & 1.01 \\
\hline
\end{tabular}


Table 22. The variation of competitive ratio of different barley varieties as determined by coefficient of variation (CV) due to the mixtures (m) and the nitrogen fertilization (n).

\begin{tabular}{llcr}
\hline Variety & Mixture & $\mathrm{CV}(\mathrm{m})$ & $\mathrm{CV}(\mathrm{n})$ \\
\hline \multirow{2}{*}{ Agneta } & two-variety & 6.5 & 4.9 \\
& three-variety & 8.9 & 6.4 \\
& four-variety & 5.6 & 5.4 \\
& two-variety & 13.3 & 0.5 \\
& three-variety & 18.2 & 0.5 \\
\multirow{3}{*}{ Kustaa } & four-variety & 13.9 & 12.7 \\
& two-variety & 13.6 & 4.0 \\
& three-variety & 15.3 & 2.4 \\
Pomo & four-variety & 16.4 & 5.6 \\
& two-variety & 10.2 & 0.5 \\
& three-variety & 16.1 & 6.9 \\
& four-variety & 16.5 & 11.9 \\
\hline
\end{tabular}

petitive relationship between the six-row variety Pomo and two-row variety Ida was inconsistent.

\section{DISCUSSION}

\section{Occurrence of yield advantage}

The comparison between the average yields of mixtures and monocultures in the second experiment of the present study suggests that the increasing number of components in the mixture might increase the yields. This agrees with the results of Nitszche and Hesselbach (1983) who grew six varieties of barley in all possible combinations. However, in the 3 -year experiment in the present study the blend responses of $0.4 \%$ (two components), $1.7 \%$ (three components) and $-0.5 \%$ (four components) did not support the argument that the yield increase of mixtures depends in general on the number of varieties combined. This agrees with the results of GIEFFERS and HESSELBACH (1988). In addition, Clay and ALLARD (1969) also found no apparent relation between the number of components and the degree of deviation from expectation.

The present results showed that the yield of the mixture was often equal to the means of the components grown in monoculture but also exceeded them. Occasionally the yield of the mixture even exceeded the highest yielding component grown alone, i.e. the mixture overyielded. However, it should be emphasized that the overyielding was never statistically significant. It was uncommon for a mixture to yield less than the mean of its components. These results agree rather well with the earlier work reviewed by SimMONDS (1962), Trenbath (1974) and Wolfe (1985). The present results are also in accordance with recent published studies of barley variety mixtures by BAKer and Briggs (1984), HouMOEller et al. (1986), KarJalainen and Hilvola (1987), GiefFers and Hesselbach (1988), Ibenthal et al. (1988) and AufhamMER and STUtZel (1989).

The results of the first experiment show that the performance of a mixture can be predicted at least reasonably well from the performance of the pure variety components. This rather close positive relationship between pure variety and mixture performance suggests that any complementary or compensatory effects that do occur are of minor importance. The range of individual blend responses observed in the second experiment ( $-6.7 \%$ to $14.5 \%$ ) may imply certain complementary and competitional effects but may also be partly due to the large random variation, which occurred in the experiment (differences over $1072 \mathrm{~kg} / \mathrm{ha}$ between the yields of the stands having different compositional structure were significant at the level of $5 \%$ ).

In addition to the comparison of the actual and expected yields of the mixtures, the de Wit model (RYT-value) was used to evaluate the productivity of mixtures. The six varieties used in the present experiments were selected in respect to contrasting agronomic types differing in yield structures, morphological characters and growing time. The mixtures were also grown under varying environmental conditions. The results of these experiments in most cases are well compatible with the de Wit competition model agreeing with the results of earlier barley varietal experi- 
ments (e.g. Sandfaer 1970, Blijenburg and SNEEP 1975). Thus, the results suggest that competition solely for the same space is rather common in mixtures of barley varieties and the yield advantage is marginal.

It should be emphasized that the RYTvalues of the mixtures of Agneta and Pomo in both experiments exceeded one. Also the RYT-values of several other mixtures in the second experiment exceeded one. This suggests that some varieties might partly occupy different spaces in certain conditions. Results from the experiments by AlLARD and ADAmS (1969) calculated by SANDFAER (1970) also indicated that some genotypes of barley may partly occupy different spaces.

\section{Reasons for yield advantage}

When deviations of RYT-values from unity occur, as at the high level of nitrogen fertilization in the present trial, some form of complementary use of resources (annidation) may be suspected (Trenbath 1974). The mechanisms resulting in the RYT-value being greater than one have been shown to be various (Trenbath 1974), but the data collected from the present experiments is limited in this respect.

Theoretically, a mixture of varieties may benefit from the association by production of a more uniform leaf distribution or by reduction of competition among integrated root systems resulting in either temporal or spatial differences of use of growth factors. The evidence from the experiments of PALvaKul et al. (1973) and LANG et al. (1975) suggests that such effects are likely to be small, or they do not favour mixing provided disease buffering is not an important factor. However, AufHAMMER and StUTZEl (1989) reported that the yield advantage of barley mixtures could not be explained by the observed levels of disease or lodging. This suggests that also other mechanisms may operate.

\section{Competitive ability and} consequences of competition

In addition to the growing season and the level of nitrogen fertilization, neighbours in the mixture were also found to influence the competitive ability of the varieties. For example, the competitive relationship between Pomo and $\mathrm{Hja} 673$ varied from year to year. Increasing nitrogen fertilization also increased the dominance of a strong aggressor, Agneta. Thus competitive ability was a relative character of a variety. In other experiments the competitive ability of barley varieties varied also due to the environment (SANDFAER 1970). These results also showed that the use of resources in mixtures is not at equilibrium in different environments.

No consistent relationship was observed between competitive ability and yield ability in pure stands of different varieties. This agrees with the results of SANDFAER (1970) and SPITTERS (1979). The results of the present study, where the competitive abilities of two- and sixrow barleys were compared, suggest that an erect type combined with greater height, as in the case of Agneta, may be more favourable. However, the competitive relationship between the six-row variety Pomo (taller, erect) and the two-row variety Ida (shorter, prostate) was unpredictable. Thus caution should be exercised in view of previous unsuccessful attempts (SAKAi 1961, VALENTINE 1982) to relate competitive ability only to an individual plant character.

The data collected in 1983 suggests that the superior competitive ability of Arra in all circumstances might be related to the early germination. Also the growth habit of Arra might favour its success in mixtures. The characters of $\mathrm{Hja} 673$ during the early stages of growth were unfavourable in the course of competition in 1983. The results of the competitive ability of the varieties in respect to the early growth agree rather well with the results of Blijenburg and Sneep (1975) and with the model constructed by SPITTERS and van den Berg (1982) and SpitTers (1984). SPITTERS 
and van den Berg (1982) concluded that the competitive ability of a plant is determined by the space it is able to occupy at the beginning of the growing season and the relative rate at which a single plant is able to expand the space it has already occupied. The varieties which were taller and had a larger leaf area during the early stages of development might shade the shorter plants, decreasing their root/shoot ratio (see Briggs 1978 p.274). The plants of the better competitor might have more light available in mixtures than in monocultures, thus increasing their root/shoot ratio.

When the competitive relationship between two genotypes as in the case of Agneta and Pomo, was rather inconsistent even the vigour of seed or the grain weight might determine the competitiveness of a genotype. This is because both characteristics of a seed were shown (KANGASMÄKI pers.com.) to affect the growth rate of seedlings.

In the present trial, some yield reductions and yield increases of the components grown in mixtures may partly be explained by the results of grain weight. Both SPITTERS (1979) and VALENTINE (1982) observed that competition between barley varieties affected more strongly the number of ears/plant and the number of grains/ear than the grain weight.

\section{Limitation of replacement series design}

The fact that the competitive ability of the six barley varieties differed in many cases from each other shows that there occurred also intergenotypic competition in mixtures. However, the limitation of the indices like CR and RY based on the replacement design is their inability to separate intra- and intergenotypic competition quantitatively from each other. Thus the results from replacement series can give only qualitative insight into the relative magnitudes of the effects of intra-and intergenotypic competition (FIRBANK and WATKINSON 1985, 1990, HÄKANSSON 1988).

The results of the experiments based on the de Wit model can be also biased, because only one density was used (ConNolly 1986). In the present experiments the indices were based on the yields per unit area of the varieties, which typically change less rapidly as the monoculture density changes than does the yield per plant. According to Harper (1977 p. 152-4) the total plant yield is rather independent of density except when plants are very small or widely spaced (the law of constant final yield). The selected density used in these experiments was very likely near optimum in respect to achieve constant final yield of barley in northern growing conditions (see e.g. ERvıö 1983).

\section{Stability of mixtures}

A frequently claimed advantage of mixtures is their capability to deal with environmental variability, implicitly equivalent to the avoidance of risk (VANDEERMEer 1989). A number of authors reviewed by TRENBATH (1974) and by Wolfe (1985) have noted the improved stability of mixtures compared with their components, but also the opposite effect has been noted.

The results of the first experiment indicate that over years only few mixtures were more stable than their most stable component in monoculture; the remaining mixtures showed stabilities between those of their component monoculture. In the second experiment the high level of nitrogen fertilization induced stress in most of the monoculture stands, decreasing the yield whereas some mixtures were insensitive to nitrogen fertilization. This suggests that a mixture may adjust its genotypic or phenotypic state in response to transient fluctuations in environment in such ways that it gives high and stable return. The advantage of mixtures in respect to stability may be partly due to the beneficial effects of compensation. Thus some mixed stands may exhibit populational buffering arising in interactions among different coexisting genotypes and show low "genotype"-environment interaction. This suggests that mixtures might be universal instead of specialized producers according to the terminology introduced by $\mathrm{AL}_{\mathrm{L}}$ LARD and BRADSHAw (1964). 
The greatest difficulty in discussing stability is the lack of any clear definition of an index of stability of yield (SCHUTZ and BRIM 1971). The standard measurement of yield variability or yield stability is the coeffiecient of variation which was also used here. One common method of measuring stability of genotypes is to regress the yield of a particular genotype to the mean yield of a group of

\section{References}

Allard, R.W. \& Adams, J. 1969. Population studies in predominantly self-pollinating species. XIII. Intergenotypic competition and population structure in barley and wheat. Amer. Nat. 103:621-645.

Allard, R.W. \& Bradshaw, A.D. 1964. Implications of genotype-environmental interactions in applied plant breeding. Crop Sci. 4:503-508.

Aufhammer, W. \& Stutzel, H. 1989. SortenMischungeffekte in Wintergerstenbeständen in Abhängigkeit von Standort und Produktionintensităt. J. Agron. Crop Sci. 162:180-191.

Aufhammer, W., Kubler, E. \& Stutzel, H. 1984. Effekte der Sortenmischung auf die Ertragsbildung von Gerstenbeständen. J. Agron. Crop Sci. 153:385-97.

BAKER, R.J. \& Brigos, K.G. 1984. Comparison of grain yield of uniblends and biblends of 10 spring barley cultivars. Crop Sci. 24:85-87.

Blijenburg, J.G. \& Sneep, J. 1975. Natural selection in a mixture of eight barley varieties grown in six successive years. 1. Competition between the varieties. Euphytica 24:305-15.

Briggs, D.E. 1978. Barley. 612 p. New. York.

Clay, R.E. \& Allard, R.W. 1969. A comparison of the performance of homogenous and heterogenous barley populations. Crop Sci. 9:407-12.

Connolıy, J.1986. On difficulties with replacementseries methodology in mixture experiments. J. Appl. Ecol. 23:125-137.

Eberhart, S.A. \& Russell, W.A. 1966. Stability parameters for comparing varieties. Crop Sci. 6:36-40.

ERvio, L.-R. 1983. Competition between barley and annual weeds at different sowing densities. Ann. Agric. Fenn. 22:232-239.

EISENBERG, B.E. 1980. Screening for competition effects amongst genotypes of barley, oats and lupins. Crop Production 9:39-47.

Firbank, L.G. \& Watkinson, A.R. 1985. On the analysis of competition within two-species mixtures of plants. J. Appl. Ecol. 22:503-517.

Firbank, L.G. \& Watkinson, A.R. 1990. On the effects genotypes over wide range of environments (see Eberhart and Russell 1966). This approach has, however, been criticized, because dependency between genotypic means and environmental means invalidates the analysis of variance of regression (ZHANG and GENG 1986). This is rather obvious in mixture experiments where the independent variable in the regression is the average of a few yields.

of competition: From monocultures to mixtures. In: Grace, J.B. \& Tilman, D.(eds.). Perspectives on Plant Competition. p. 166-192. Academic Press, Inc. New York.

Giefrers, W. \& Hesselbach, J. 1988. Krankheitsbefall und Ertrag verschiedener Getreidesorten im Rein- und Mischanbau. I. Sommergerste (Hordeum vulgare L.). Z. Pfl.krankheiten Pfl.schutz 95:46-62.

Häkansson, S. 1988. Competition in stands of short-lived plants. Density effects measured in three-component stands. Swed. Univ. Agric. Sci. Dept. Crop Production Sci. Crop Production Sci. 3. 181 p. Uppsala.

Harper, J.L. 1977. Population Biology of Plants. 892 p. Academic Press. London.

Harrabi, M.M., Laribi, A. \& Bouslama, M. 1986. Stability and yield performance of some barley (Hordeum vulgare L.) cultivars and mixtures. Rachis, Barley and Wheat Newsl.5:11-16.

Houmoller, M.S., Henneberg, U., Olsen, C.C., Stolen, O. \& Welling, B. 1986. Sortsblandinger af vinterbyg 1983-85. Tidskr. Planteavl. 90:15-26.

Ibenthal, W-D., Gobel, M., Willnecker, G. \& BernHOLD, L. 1988. Ertragsniveau, Krankheitsbefall und Mehltauvirulenz in Sortenmischungen von Sommergerste (1984-1986). Z. Pfl.krankheiten Pfl.schutz 95:561-571.

Karjalainen, R. \& Hitvola, S.-L. 1987. Performance of cultivar mixtures under northern growing conditions in Finland. Barley Genet. V:719-725.

LANG, R.W., Holmes, J.C., TAYlor, B.R. \& Waterson, H.A. 1975. The performance of barley variety mixtures. Expl. Husb. 28:53-59.

Mcdonald, B.A., Allard, R.W. \& Webster, R.K. 1988. Responses of two-, three-, and four-component barley mixtures to a variable pathogen population. Crop Sci. 28:447-452.

Nitzshe, W. \& Hesselbach, J. 1983. Sortenmischungen statt Viellien-Sorten. 1. Sommergerste (Hordeum vulgare L.). Z. Pfl.zuchtg. 90:68-74.

Palvakul, M., Finkner, V.C. \& Davis, D.L. 1973. 
Blendability of phenotypically similar and dissimilar winter barley cultivars. Agron. J. 65:74-77.

Rantanen, O. \& Simojokı, P. 1987. Ohra. Peltokasvilajikkeet $1987-88$. Tieto tuottamaan $45: 28-35$. Helsinki.

SAKAI, K.I. 1961. Competitive ability in plants: its inheritance and some related problems. Symp. Soc. Expl. Biol. 15:245-263.

SAndfaer, J. 1970. An analysis of the competition between some barley varieties. Risö Rep. 230. Danish atomic energy commission. 114 p. Roskilde.

Schutz, W.M \& Brim, C.A. 1971. Inter-genotypic competition in soybeans. III. An evaluation of stability. Crop Sci. 11:684-689.

Simmonds, N.W. 1962. Variability in crop plants, its use and conservation. Biol. Rev. 37:442-465.

SPITters, C.J.T. 1979. Competition and its consequences for selection in barley breeding. Agric. Res. Rep. 893. 268 p. Wageningen.

SPITTERS, C.J.T. 1984. Effects of intergenotypic competition on selection. Proceed. 10th Congr. Eur. Assoc. Res. Pl. Breed. EUCARPIA. p.13-27. Wageningen.

Spitters, C.J.T. \& Berg, J.P. van den. 1982. Competition between crop and weeds: A system approach. In: Holzner, W. \& Numata, N.(eds.). Biology and Ecology of Weeds. p.137-148. Hague.

Steel, R.G.D. \& Torrie, J.H. 1980. Principles and Procedures of Statistics. A Biometrical Approach. 2nd
Edition. 633 p. McGraw-Hill Kogakusha, Ltd. Tokyo. TRENBATH, B.R. 1974. Biomass productivity of mixtures. Adv. Agron. 26:177-210.

VAlentine, J. 1982. Variation in monoculture and in mixture for grain yield and other characters in spring barley. Ann. Appl. Biol. 101:127-141.

VANDERMEeR, J. 1989. The Ecology of Intercropping. 237 p. Cambridge University Press. Cambridge.

WILLEY, R.W. 1979. Intercropping - Its importance and research needs. Part 1. Competition and yield advantages. Field Crop Abstr. 32:1-10.

WILleY, R.W. 1985. Evaluation and presentation of intercropping advantages. Exp. Agric. 21:119-133.

WILley, R.W. \& RAO, M.R. 1980. A competitive ratio for quantifying competition between intercrops. Exp. Agric. 16:117-125.

WIr, C.T. de. 1960. On competition. Versl. Landbouwk. Onderz. 66.8:1-88.

WiT, C.T. de. \& BerG, J.P. van den. 1965. Competition between herbage plants. Neth. J. Agric. Sci. 13:212-221.

wOLFE, M.S. 1985. The current status and prospects of multiline cultivars and variety mixtures for disease resistance. Ann. Rev. Phytopath. 23:251-73.

Zhang, Q \& GenG, S. 1986. A method of estimating varietal stability for data of long term trials. Theor. Appl. Genet. 71:810-814.

\title{
SELOSTUS
}

\section{Ohralajikkeiden välinen kilpailu ja lajikeseosten sato}

\author{
Kari Jokinen
}

Helsingin Yliopisto, Kasvinviljelytieteen laitos

00710 Helsinki

Nykyinen osoite

Kemira Oy, Espoon tutkimuskeskus,

PL 44, 02271 Espoo

Kahdessa korvaussarjaan perustuvassa kenttäkokeessa tutkittiin ohralajikkeiden vălistä kilpailua ja seosten sadontuottoa seosten koostuessa kahden, kolmen ja neljăn lajikkeen yhdistelmistă. Ensimmäisessă kokeessa, joka toistettiin kolmena peräkkăisenă vuonna (1983-85), lajikkeet olivat monitahoiset Agneta, Arra, Hja-673 ja Pomo. Toisessa kokeessa (1984), jossa kăytettiin myös kahta typpilannoituksen mäărää ( $50 \mathrm{ja} 100 \mathrm{kgN} / \mathrm{ha})$, lajikkeet olivat monitahoiset Agneta ja Pomo ja kaksitahoiset Ida, Kustaa.

Lajikkeen valtauskyky ei yleensä ollut genotyypin stabiili ominaisuus lajikkeiden keskinäisten valtaussuhteiden muuttuessa ympäristöstä toiseen (kasvukausi, typpilannoitus). Lajikkeen valtauskyky ei riippunut lajikkeen aikaisuudesta, morfologisista ominaisuuksista (kaksi- ja monitahoiset) eikä puhdaskasvustosadon määrästă. Lajikkeen valtauskykyä edisti nopea alkukehitys Arran ollessa valtaavin lajike.

Ensimmäisen kokeen yhdenkäăn seoksen kolmen vuoden keskimäăräinen jyväsato ei poikennut tilastollisesti 
merkitsevästi seoksen komponentin puhdaskasvuston jyväsadosta. Toisessa kokeessa joidenkin seosten jyväsato oli tilastollisesti merkitsevästi suurempi kuin seoksen komponenteista văhiten tuottaneen puhdaskasvustosato. Vaikka useiden seosten toteutuneen ja odotetun sadon vălinen suhde ja seoksen suhteellinen kokonaissato oli hiu- kan suurempi kuin yksi, oli seosten satoetu marginaalinen. Yksiselitteisesti seokset eivät olleet vakaampia sadontuottajia kuin puhdaskasvustot vaihtelukertoimella mitattuna. Joidenkin seosten jyväsato kuitenkin vaihteli văhemmăn kuin văhiten vaihtelevan komponentin puhdaskasvuston jyväsato. 